
ON BIODENTAL ENGINEERING

\title{
CONFERENCE PROGRAM and ABSTRACTS
}

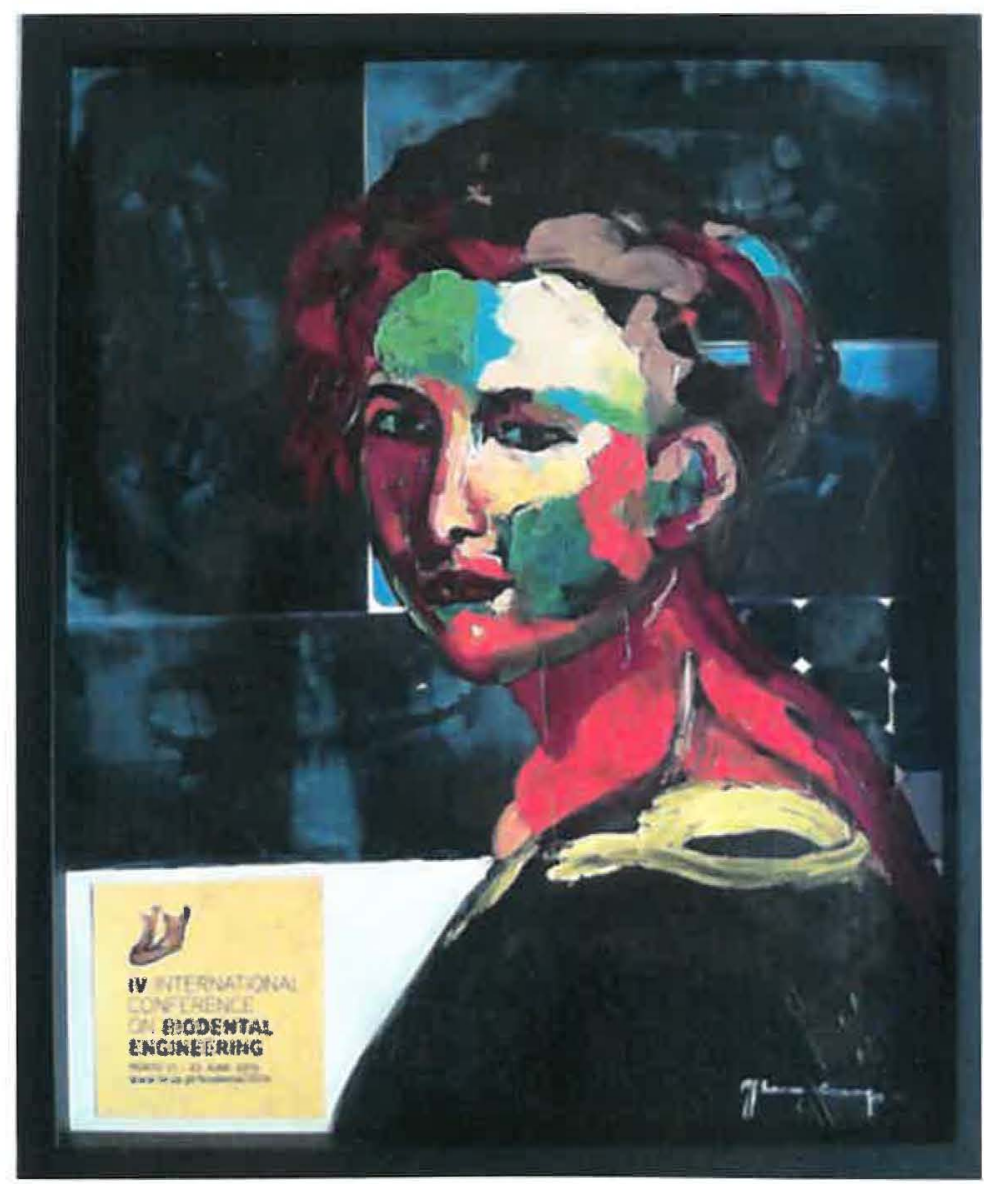

Vila Nova de Famalicão

Portugal 


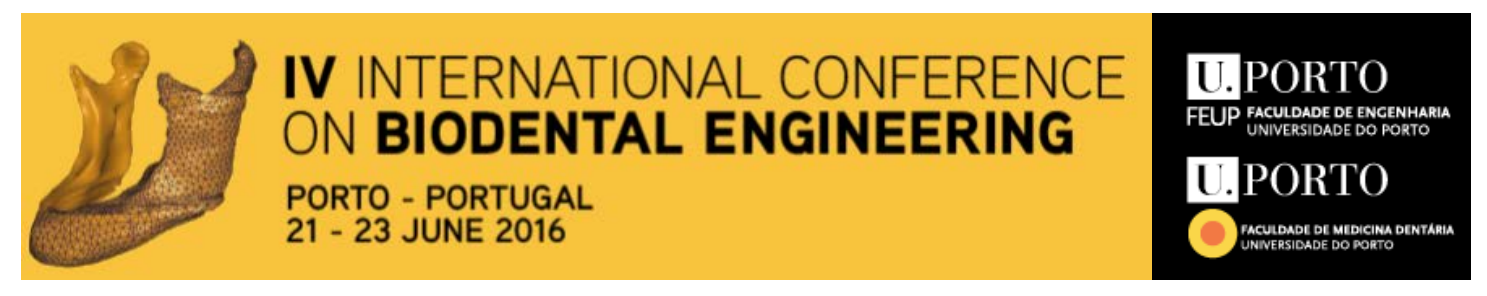

\section{CONFERENCE PROGRAM and ABSTRACTS}

\section{0 inequ=}
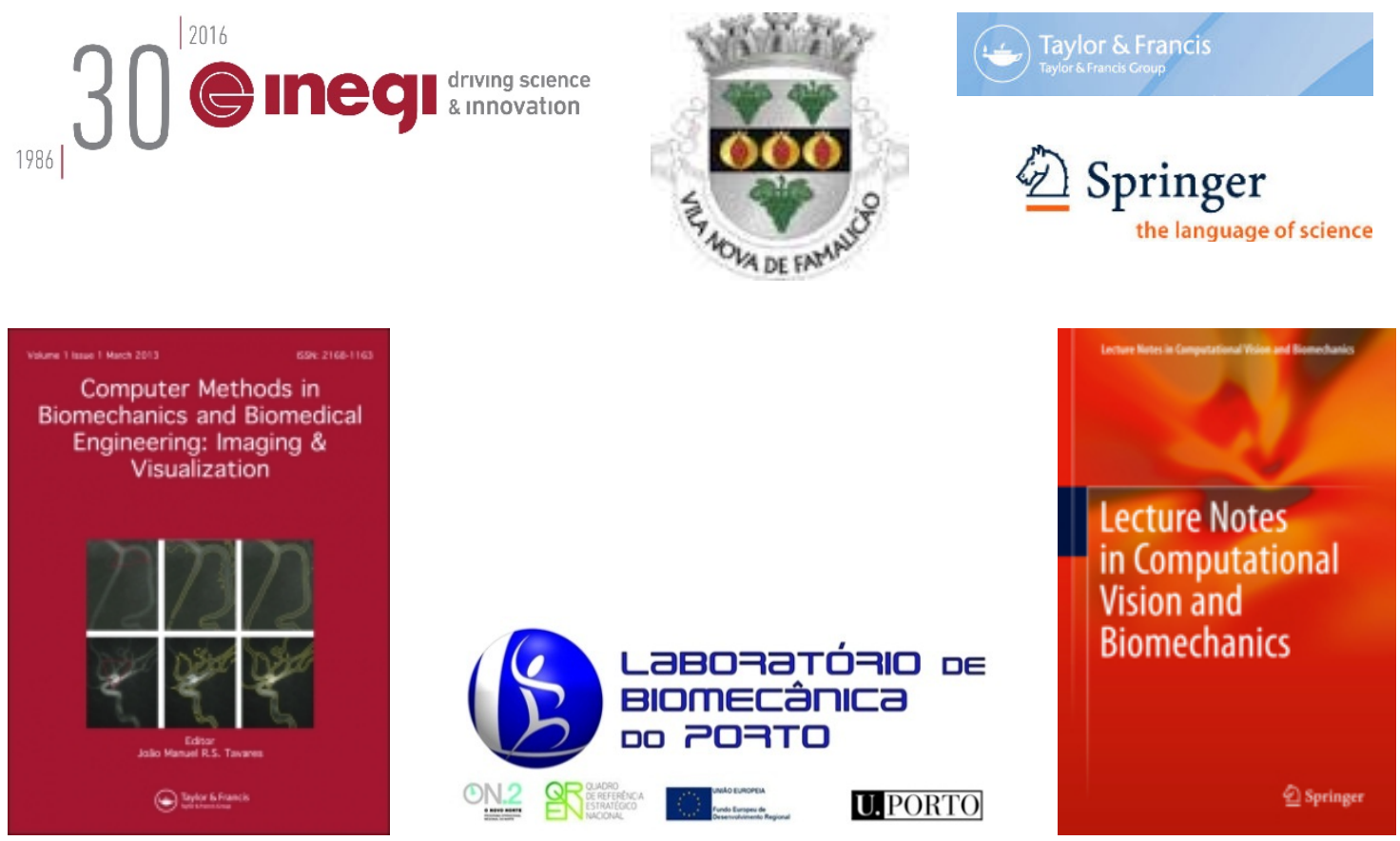

\section{Organizing Committee}

Renato Natal J orge

Reis Campos

Mário Vaz

Sónia Santos

J oão Manuel R. S. Tavares 


\section{INTERNATIONAL CONFERENCE ON BIODENTAL ENGINEERING

\section{Honorary Committee}

Dr Paulo Cunha

Dr Nuno Melo

Dr António Barbosa

Dr Rui Maia

\section{Scientific Committee}

Afonso Pinhão Ferreira

Amaya Pérez

António Completo

André Correia

António Ramos

António Torres Marques

Augusta Neto

Carla Roque

Cláudia Barros Machado

Cornelia Kober

Daniela I acoviello

Edson Capello

Luis Vieira Pinto

Elza Maria Morais Fonseca

Estevam Las Casas

Fernanda Gentil

Fernando Guerra

Filipe Silva

Gerhard A. Holzapfel

Maria Helena Figueiral

Henrique Almeida

Hernani Miguel Reis Lopes

I oannis Misirlis

I racema Braga

J oão Batista Novaes Júnior

J oão Carlos Pinho

J oão Eduardo Ribeiro

J oão Manuel Tavares

J oão Paulo Flores Fernandes

J oaquim Gabriel

J ohn Middleton

Jorge Belinha

J oão Leite-Moreira

Jorge Marinho

José Mário Rocha
J osep Torrent

Kazem Alemzadeh

Leopoldo Forner Navarro

Luis Geraldo Vaz

Luís Pires Lopes

Luís Roseiro

Marco Parente

Margarida Sampaio Fernandes

Mà Jesús Mora

Ma Manzanares Céspedes

Maria J oão Ponces

Mário Forjaz Secca

Mário Vasconcelos

Mário Vaz

Miguel Pinto

Mildred Ballin Hecke

Pablo Rodríguez Cervantes

Patrícia Fonseca

Paula Vaz

Paulo Gonçalves Piloto

Paulo Melo

Paulo Rui Fernandes

Pedro Martins

Pedro Mesquita

Pedro Gomes Nicolau

Reis Campos

Renato Natal J orge

Sampaio Fernandes

Sílvia Barbeiro

Teresa Pereira Leite

Urbano Santana-Mora

Urbano Santana-Penin

Vicente Campos

Yongjie (J essica) Zhang 


\section{Partners}

Câmara Municipal de Vila Nova de Famalicão

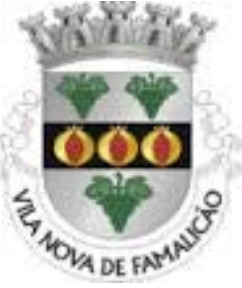

Casa das Artes: integrated in Biodental a painting exposition is presented

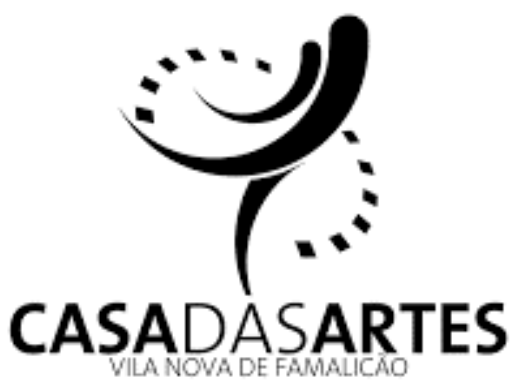

Centros auditivos Widex

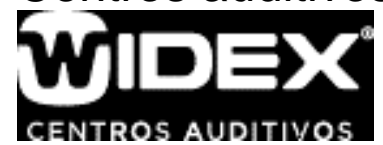

Biodental 2016 was organized in the scope of Project NORTE-01-0145-FEDER000022 - SciTech - Science and Technology for Competitive and Sustainable Industries, cofinanced by Programa Operacional Regional do Norte (NORTE2020), through Fundo Europeu de Desenvolvimento Regional (FEDER).

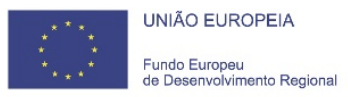




\section{VENUE}

Casa das Artes

Av. Carlos Bacelar

Parque de Sinçães

4760-103 Vila Nova de Famalicão

http://www.casadasartes.org/

GPS Coordinates:

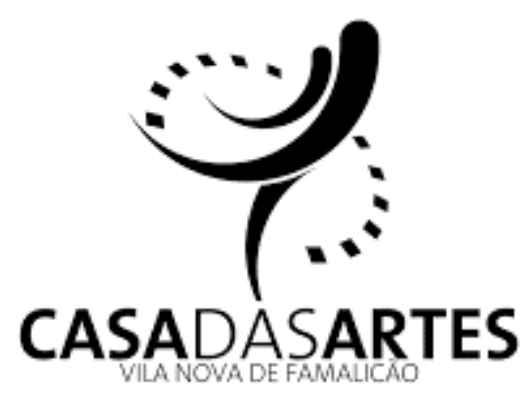

$\mathrm{N}: 41^{\circ} 24^{\prime} 50^{\prime \prime}$

W: $8^{\circ} 31^{\prime} 03^{\prime \prime}$

Telf.: +351252371304 / +351252371297

e-mail: casadasartes@vilanovadefamalicao.org

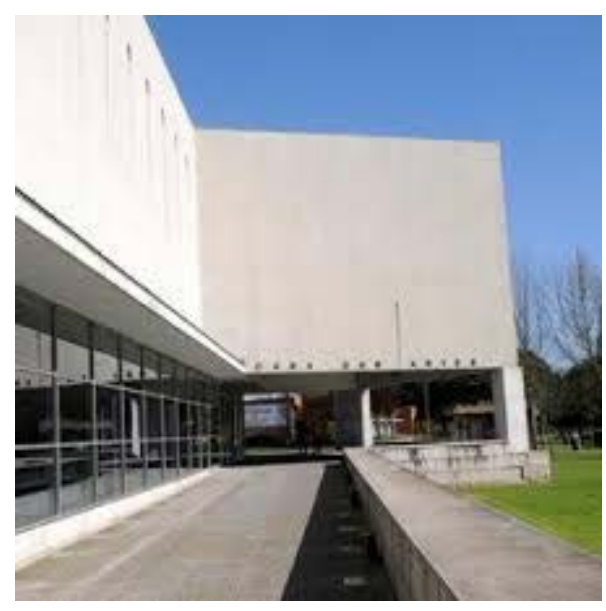




\begin{tabular}{|c|c|}
\hline & $\begin{array}{c}\text { Tuesday } \\
\text { Room: 'Pequeno Auditório' }\end{array}$ \\
\hline 10: 30 & Registration \\
\hline $11: 30$ & Opening Session \\
\hline \multirow[b]{2}{*}{$12: 00$} & $\begin{array}{l}\text { Oral presentations - Session I } \\
\text { Chairpersons: Mário Vaz / Fernanda Gentil }\end{array}$ \\
\hline & $\begin{array}{l}\text { MANDIBLE ANOMALIES - HOW CAN TWO-DIMENSIONAL ULTRASOUND } \\
\text { HELP? } \\
\text { Inês Côrte-Real, Rosete Nogueira, Ana Cristina Braga, António Felino, } \\
\text { Vicente Campos, Francisco Valente, Paula Vaz } \\
\text { TRIDIMENSIONAL SCAFFOLDS IN BONE REGENERATION } \\
\text { Mariane Beatriz Sordi, Isis Carvalho Encarnação, Águedo Aragonês, Mabel } \\
\text { Mariela Rodriguez Cordeiro, Ricardo de Souza Magini } \\
\text { DEGRADATION OF DENTAL IMPLANT SYSTEMS AFTER IMMERSION IN } \\
\text { THERAPEUTIC GELS } \\
\text { Gabriella M. P. Juanito, Maithe S. Araujo, Filipe S.Silva, Ricardo S. Magini, } \\
\text { Júlio C. M. Souza } \\
\text { PALATAL OBTURATORS FOR CLEFT PALATE PATIENTS } \\
\text { Marco António Silva, André Correia, Vicente Campos, Teresa Pereira } \\
\text { Leite, Reis Campos }\end{array}$ \\
\hline 13:00 & Lunch (Massimo Restaurante) \\
\hline
\end{tabular}


Tuesday

Room: 'Pequeno Auditório'

\section{Oral presentations - Session II}

Chairpersons: J oão Tavares / Paula Vaz

CONVERGENCE ANGLE OF PREPARED TEETH FOR FULL CROWNS Inês Meireles Silva, Alexandra Matos Oliveira, Paulo Rocha-Almeida, Paula Vaz, César Silva, J oão Sampaio-Fernandes

VIRTUAL DIE-SPACING - EVEREST ${ }^{\circledR}$ (KAVO ${ }^{\circledR}$ ) SYSTEM EVALUATION Paulo Rocha-Almeida, JC Reis Campos, Tiago Coutinho Almeida, Paula Vaz, César Silva, J oão Sampaio-Fernandes

SURFACE FINISHING IN TOOTH PREPARATION FOR FIXED PROSTHODONTICS - COMPARATIVE STUDY

$14: 30$ Estevão Correia, Paulo Rocha-Almeida, Manuel A Sampaio-Fernandes, Paula Vaz, César Silva, J oão Sampaio-Fernandes

DERMAL ZIGOMATIC PERI-IMPLANT REACTION - GENE EXPRESSION? Margarida Sampaio-Fernandes, Luís Tovim, Levi Rau, César Silva, J oão Sampaio-Fernandes, Paula Vaz

KAVO PREPASSISTANT ${ }^{\circledR}$ SYSTEM: RELIABILITY

Francisco Maligno, Kevin Oliveira, Paulo Rocha-Almeida, J oão Carlos Pinho, João Sampaio-Fernandes

IMPLANT STABILITY QUOTIENT (ISQ) - FROM SURGERY TO PROSTHETIC REHABILITATION

MA Sampaio-Fernandes, Luís Guilherme Pimentel, Nuno Mesquita

Marques, J C Sampaio-Fernandes, Paulo Júlio Almeida 


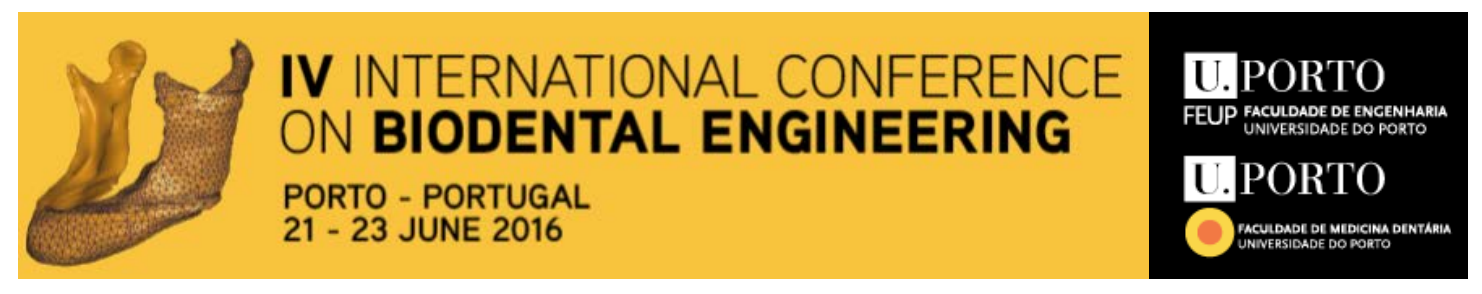

\begin{tabular}{|c|c|}
\hline & $\begin{array}{c}\text { Wednesday } \\
\text { Room: 'Pequeno Auditório' }\end{array}$ \\
\hline 09: 30 & $\begin{array}{l}\text { Invited Lecture } \\
\text { Beyond the Smile: Psychological Readings of the Teeth in Painting } \\
\text { Sofia Torres, Faculdade de Belas Artes da Universidade do Porto } \\
\text { Chairperson: Reis Campos }\end{array}$ \\
\hline 10: 30 & Coffee break \\
\hline \multirow[b]{2}{*}{ 11:00 } & $\begin{array}{l}\text { Oral presentations - Session I I I } \\
\text { Chairpersons: JC Sampaio-Fernandes / Marco Parente }\end{array}$ \\
\hline & $\begin{array}{l}\text { DETERMINATION OF OPTIMAL PARAMETERS IN DRI LLING COMPOSITE } \\
\text { MATERI ALS TO MI NI MIZE THE MACHINING TEMPERATURE USING The } \\
\text { TAGUCHI METHOD } \\
\text { Ana C. Lopes, Maria G. A. Fernandes, João E. Ribeiro, EIza M.M. Fonseca } \\
\text { CYCLIC TORSIONAL TESTING OF TITANIUM AND ZIRCONI A DENTAL } \\
\text { IMPLANTS } \\
\text { Marco Martins, José Reis, M. Fátima Vaz, Luís G. Reis } \\
\text { TRIDIMENSIONAL SCAFFOLDS IN BONE REGENERATION } \\
\text { Mariane Beatriz Sordi, Isis Carvalho Encarnação, Águedo Aragonês, Mabel } \\
\text { Mariela Rodriguez Cordeiro, Ricardo de Souza Magini } \\
\text { NEW STRATEGIES TO ZIRCONIA IMPLANT APPLICATIONS } \\
\text { Rafael S. F. Pereira, Filipe S. P. Silva, Bruno Henrique, Márcio C. Fredel } \\
\text { INFLUENCE OF SELECTIVE ETCHING ON MARGINAL FILTRATION OF } \\
\text { SELF-ETCHING ADHESIVES } \\
\text { Sebastiana Arroyo Bote, X. Martínez Arroyo, Ma C. Manzanares Céspedes } \\
\text { MECHANICAL PROPERTIES OF ORTHODONTIC ARCHWIRES: INFLUENCE } \\
\text { OF TYPE OF ALLOY AND SURFACE COATING } \\
\text { Spalj S, Musa Trolic I, Katic V, Turco G, Contardo L. } \\
\text { EFFECT OF DRILL SPEED ON BONE DAMAGE DURING DRILLING } \\
\text { Maria G Fernandes, Lucas Azevedo, Renato Natal J orge, Elza M M } \\
\text { Fonseca, João E P C Ribeiro } \\
\text { EFFECT OF THE CHANGE IN THE PH VALUE OF ARTIFICIAL SALIVA ON } \\
\text { MECHANICAL PROPERTIES OF ORTHODONTIC ARCHWIRES } \\
\text { Katic V, Kamenar E, Zelenika S, Marković K, Spalj S }\end{array}$ \\
\hline 13:00 & Lunch (Massimo Restaurante) \\
\hline
\end{tabular}




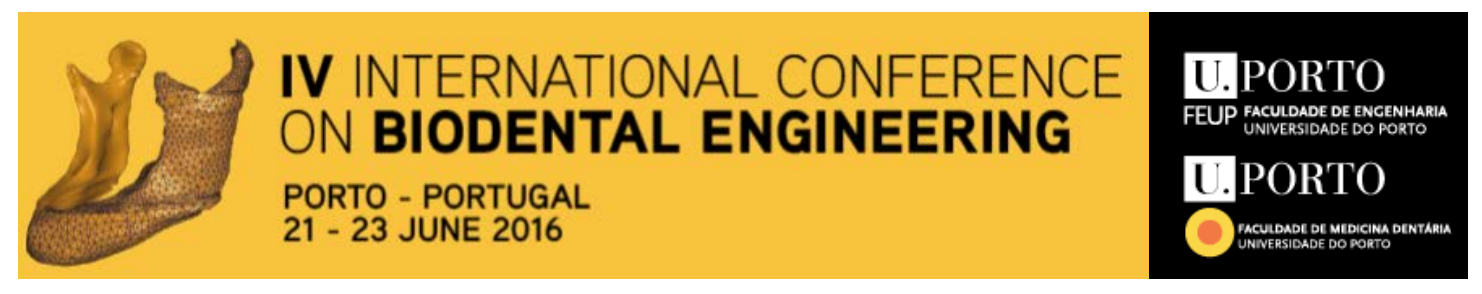

\begin{tabular}{|c|c|}
\hline & $\begin{array}{c}\text { Wednesday } \\
\text { Room: 'Pequeno Auditório' }\end{array}$ \\
\hline \multirow[b]{2}{*}{$14: 30$} & $\begin{array}{l}\text { Oral presentations - Session IV } \\
\text { Chairpersons: Maria Helena Figueiral / Elza Fonseca }\end{array}$ \\
\hline & $\begin{array}{l}\text { AN OVERVIEW OF DENTAL IMPLANT MATERIALS } \\
\text { S. Madeira, O. Carvalho, G. Miranda, J. Caramês, F.S. Silva } \\
\text { BENEFITS OF MULTI-LAYERED MATERI ALS IN DENTISTRY } \\
\text { Júlio C. M. Souza, Bruno Henriques, Marcio C. Fredel, Filipe S. Silva } \\
\text { STRESS DISTRIBUTION AROUND ANGLED IMPLANTS WITH DIFFERENT } \\
\text { LENGHTS: AN IN VITRO ANALYSIS } \\
\text { J oana Xavier, Tiago Borges, Marco Parente, Ricardo Faria-AImeida, João } \\
\text { Manuel R.S. Tavares } \\
\text { SURFACE CHANGES (SCANNING ELECTRON MICROSCOPE) INDUCED BY } \\
\text { ARTIFICIAL SALIVA IN STAINLESS STEEL ORTHODONTIC LOOPS } \\
\text { Saúl Castro, Eugénio Martins, Maria Ponces, Jorge Lopes; Maria Pollmann } \\
\text { EXPERIMENTAL STUDY OF A NEW BIOMEMBRANE (MES) FOR GUIDED } \\
\text { BONE REGENERATION } \\
\text { Raquel Zita Gomes, I sabel Guerra, Américo Afonso, Maria Helena } \\
\text { Fernandes, José Cavalheiro, Mário Vasconcelos, Antonio Felino } \\
\text { SURFACE ROUGHNESS OF STAINLESS STEEL ORTHODONTIC LOOPS IN } \\
\text { ARTIFICIAL SALIVA } \\
\text { Saúl Castro, Ramiro Martins, Reis Campos, Paulo Teles, Maria Pollmann } \\
\text { FLEXI BLE PROSTHESIS IN POLYAMIDE - LITERATURE REVISION } \\
\text { Rui Costa, Maria Helena Figueiral, J osé Reis Campos } \\
\text { DENTURE ADHESIVES - A REVIEW } \\
\text { Carlos Almeida, Margarida Sampaio-Fernandes, J osé Reis Campos, José } \\
\text { Mário Rocha, Maria Helena Figueiral, J oão Sampaio-Fernandes } \\
\text { FIXED PROSTHODONTICS - CLINICAL VERSUS PRE-CLI NICAL PRACTICE } \\
\text { Carlos Almeida, Rui Machado, Orlando Lino, César Silva, J oão Carlos } \\
\text { Sampaio-Fernandes }\end{array}$ \\
\hline $17: 00$ & Coffee break \\
\hline
\end{tabular}


Wednesday

Room: 'Pequeno Auditório'

\section{Thematic Session on}

Numerical Remodelling Analysis of Bone Tissue - Session I

Organizers:

Jorge Belinha (INEGI-FEUP), Mạ Cristina Manzanares Céspedes (U Barcelona), António Completo (U Aveiro), Susana Vinga (IDMEC-IST)

THE ANALYSIS OF BAR IMPLANTS: A NUMERICAL STUDY

J. Belinha, L.M.J.S. Dinis, R.M.Natal Jorge

STRESS ANALYSIS OF 3D TRABECULAR PATCHES: A COMPARISON STUDY

C.I.R.A Maia dos Santos, M.C. Marques, J.Belinha, M.C. Manzanares

$17: 30$ Céspedes, Catherine Chaussain, R.M. Natal Jorge

BIPARTITE MEDIAL CUNEIFORM X-ray MICROTOMOGRAPHIC ( $\mu C T)$ IMAGE ANALYSIS

Alicia Baltasar-Sánchez, Ángel González-Sistal, Miquel Dalmau-Pastor, Betlem Fargues-Polo, Maria-Cristina Manzanares-Céspedes

A 2D STRESS ANALYSIS OF ZIRCONIA DENTAL IMPLANTS: A COMPARISON STUDY

L.G.Piqueiro, J.Belinha, A.M.R.Correia, L.M.J.S.Dinis, R.M.Natal Jorge

MICROSCOPIC AND ULTRAMICROSCOPIC ANALYSIS of "IN VIVO" TREPHINE PATIENT'S BIOPSIES

I. Valdivia-Gandur, E. Sánchez-Garcia, V. Beltrán-Varas, R. FuentesFernández, W. Engelke, C. Bucchi-Morales, MC. Manzanares-Céspedes

THE NUMERICAL ANALYSIS OF ANGLED ABUTMENTS USING ADVANCED DISCRETIZATION TECHNIQUES

R.O.S.S. Costa, J. Belinha, L.M.J.S. Dinis, R.M. Natal Jorge 


\section{CONFERENCE DI NNER}

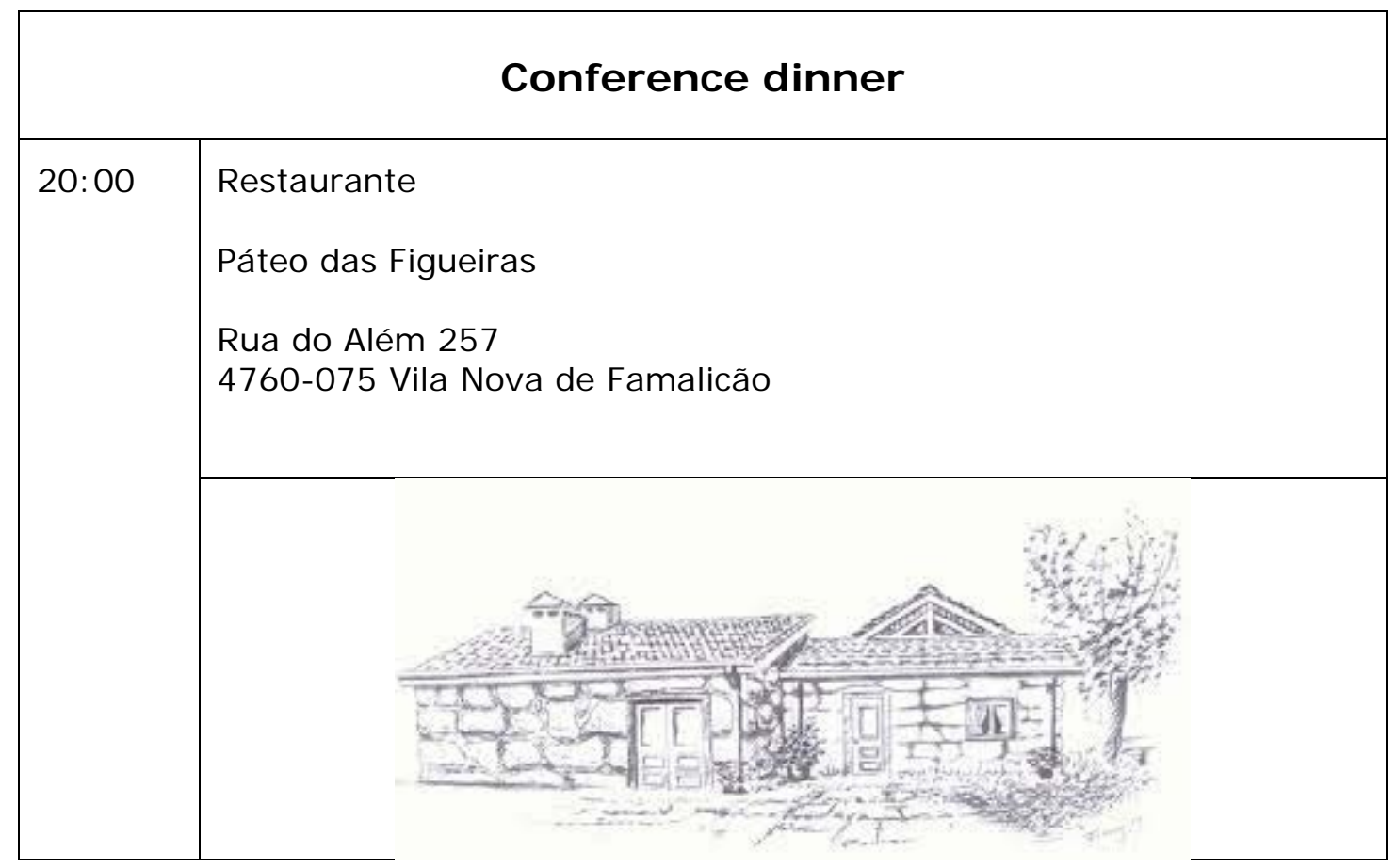


Thursday

Room: 'Pequeno Auditório'

\section{Thematic Session on}

Numerical Remodelling Analysis of Bone Tissue - Session II

Organizers:

Jorge Belinha (INEGI-FEUP), Mạ Cristina Manzanares Céspedes (U Barcelona), António Completo (U Aveiro), Susana Vinga (IDMEC-IST)

09: 15

DEVELOPMENT OF A STAND-ALONE SOFTWARE IN MATLAB TO RECOGNIZE MULTI-SCALE BONE STRUCTURES BONE

M. Marques, J. Belinha, M.C. Manzanares Céspedes, Catherine Chaussain, R.M. Natal J orge

\begin{tabular}{|c|c|}
\hline 09: 15 & $\begin{array}{l}\text { EFFECTS OF DYNAMIC COMPRESSION ON CELLS IN TISSUE } \\
\text { ENGINEERING OF MANDI BULAR CONDYLAR CARTI LAGE } \\
\text { S. Cortez, A. Completo, J.L. Alves } \\
\text { A NEW BONE TISSUE REMODELLING ALGORITHM COMBINING THE } \\
\text { MECHANICAL STIMULI WITH CELLULAR DYNAMICS } \\
\text { M. Peyroteo, J. Belinha, S. Vinga, L.M.J.S. Dinis, R.M. Natal J orge } \\
\text { INFLUENCE OF POROSITY AND CELL DENSITY ON TISSUE ENGINEERING } \\
\text { OF MANDI BULAR CONDYLAR CARTILAGE } \\
\text { S. Cortez, A. Completo, J.L. Alves } \\
\text { ENDODONTIC-PERIODONTAL LESIONS: A 2D COMPUTATIONAL STUDY } \\
\text { P.F.O. Lopes, J. Belinha, L.M.J.S. Dinis, R.M. Natal J orge }\end{array}$ \\
\hline 30 & Coffee break \\
\hline
\end{tabular}




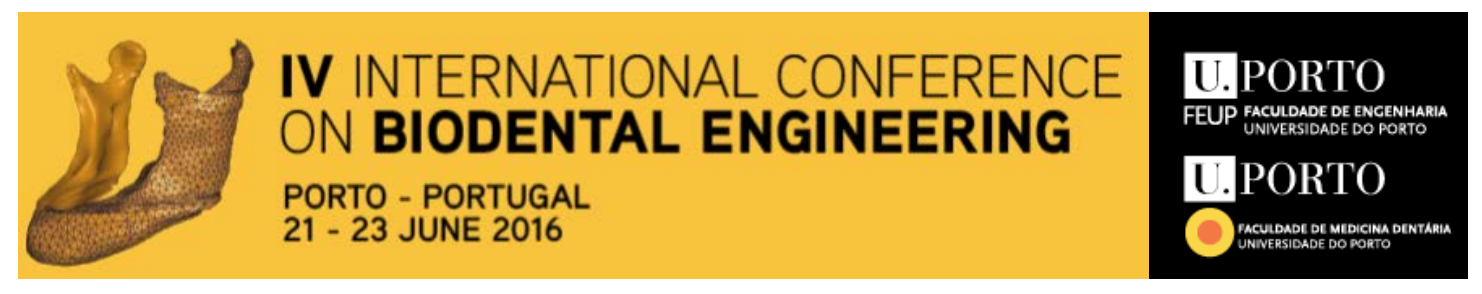

\begin{tabular}{|c|c|}
\hline & $\begin{array}{c}\text { Thursday } \\
\text { Room: 'Pequeno Auditório' }\end{array}$ \\
\hline \multirow[b]{2}{*}{$11: 00$} & $\begin{array}{l}\text { Oral presentations - Session V } \\
\text { Chairpersons: Margarida Sampaio-Fernandes / Renato Natal J orge }\end{array}$ \\
\hline & $\begin{array}{l}\text { DEVELOPMENT, LABORATORY AND CLINICAL EVALUATION OF A TMJ } \\
\text { DISTRACTION DEVICE FOR PATIENTS WITH ARTICULAR DISORDERS } \\
\text { DIAGNOSIS - THE PROJ ECT. } \\
\text { Júlio Fonseca, Luís Roseiro, Pedro Nicolau } \\
\text { I MAGE PROCESSING TECHNIQUES AND ORTHODONTIC RELATED APICAL } \\
\text { ROOT RESORPTION PREDICTION MODELS } \\
\text { Sónia Alves, Henriqueta Silva, Luís Mesquita, Nuno Lavado, Miguel Lopez } \\
\text { IN VITRO ACCURACY AND SENSIBILITY OF A COMPUTERIZED OCCLUSAL } \\
\text { ANALYSIS SYSTEM: T-SCAN III HD } \\
\text { Júlio Fonseca, Mário Martins, Pedro Nicolau } \\
\text { ARTICULATING PAPER MARKINGS I NTERPRETATION CANNOT } \\
\text { ACCURATELY DETERMINE OCCLUSAL FORCE } \\
\text { Júlio Fonseca, Joana Pereira, Pedro Nicolau } \\
\text { IN VITRO STUDY OF ANTIFUNGAL DRUG EFFECT IN A TISSUE } \\
\text { CONDITIONER } \\
\text { Bibiana M. AsSunção, Mariana Henriques, Célia F. Rodrigues, Paula Vaz, } \\
\text { Helena Figueiral, Ana Cristina Braga, Sampaio Fernandes } \\
\text { RESIDUAL RIDGE RESORPTION IN PATIENTS WITH MANDIBULAR } \\
\text { KENNEDY CLASS I REMOVABLE PARTIAL DENTURES } \\
\text { Ana MesSias, Fernando Guerra, Maria Augusta Neto, Pedro Nicolau } \\
\text { PATIENT-SPECIFIC RECONSTRUCTION UTILIZING COMPUTER ASSISTED } \\
\text { 3D MODELLING FOR PARTIAL BONE FLAP DEFECT IN CRANIOPLASTY } \\
\text { Low Peh Hueh, J ohari Yap, Abdul Manaf Abdullah, Suzana Yahya, Zamzuri } \\
\text { Idris, Zainul Ahmad Rajion, Dasmawati Mohamad }\end{array}$ \\
\hline $12: 30$ & Closing Session \\
\hline 13:00 & Lunch (Massimo Restaurante) \\
\hline
\end{tabular}




\title{
DETERMINATION OF OPTIMAL PARAMETERS IN DRILLING COMPOSITE MATERIALS TO MINIMIZE THE MACHINING TEMPERATURE USING THE TAGUCHI METHOD
}

\author{
Ana C. Lopes (1), Maria G. A. Fernandes (2), João E. Ribeiro (3), Elza M.M. Fonseca (4) \\ Polytechnic Institute of Bragança, Portugal \\ 1. anacatarina.lopes@outlook.com \\ INEGI, Faculty of Engineering of University of Porto, Portugal \\ 2. mgfernandes@inegi.up.pt \\ LAETA, INEGI, Polytechnic Institute of Bragança, Portugal \\ 3. jriberio@ipb.pt; 4. efonseca@ipb.pt
}

$(4)$

\section{Introduction}

Dental implant is used to replace the natural dental root. The process to fix the dental implant in the maxillary bone needs a previous drilling operation. This machining operation involves the increasing of temperature in the drilled region which can reach values higher than $47^{\circ} \mathrm{C}$ and for this temperature is possible to occur the osseous necrosis [1]. The main goal of this work is to implement an optimization method to define the optimal drilling parameters that could minimize the drilling temperature. The proposal optimization method is the Taguchi method. This method has been used with success in machining processes optimization of metallic materials [2]. However, the Taguchi method is also used in medical applications, namely in dental medicine [3]

\section{Material and methods}

For this study were used blocks of Sawbones in composite material (Figure1), a computer, a MGC data acquisition system, type $\mathrm{K}$ thermocouples and a CNC machine programmed to drill the blocks.
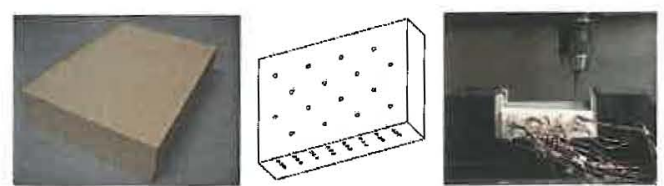

Figure1: Sawbones block (left), Solidworks drawing with marking holes and block drilling, thermocouples [4].

Several tests were performed and it was possible to record the temperature in the material for different depths as can be seen in Figure 2. The material used is a composite which has mechanical properties similar to cortical bone.

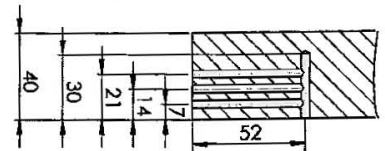

Figure2: Position of the thermocouples.

To implemented the experimental tests was used the Taguchi orthogonal array L18 with three parameters. In table 1 is presented the parameters and their levels.
Table 1: Parameters and their levels used in experimental tests.

\begin{tabular}{clccc}
\hline Symbol & Cutting Parameters & Level 1 & Level 2 & Level 3 \\
\hline A & Irrigation & Yes & No & - \\
B & Spindle Speed [rpm] & 600 & 800 & 1200 \\
C & Position & 7 & 14 & 21 \\
\hline
\end{tabular}

For each combination of parameters and levels were measured the temperature with the thermocouples. Using the obtained results was implemented an ANOVA analysis which is represented in table 2 .

Table 2: ANOVA analysis of results.

\begin{tabular}{lcc|c|c|c|c}
\hline Source & DF & Adj SS & Adj MS & F-Value & P-Value & \% Contribution \\
\hline A & 1 & 110.18 & 110.18 & 43.57 & $\mathbf{0 . 0 6 0}$ & 51.1 \\
B & 2 & 66.374 & 33.187 & 13.12 & 0.001 & 30.8 \\
C & 2 & $\mathbf{8 . 7 0 2}$ & 4.351 & $\mathbf{1 . 7 2}$ & $\mathbf{0 . 2 2 0}$ & 4.0 \\
Error & 12 & 30.346 & 2.529 & & & 14.1 \\
\hline Total & 17 & 215.602 & & & & \\
\hline
\end{tabular}

\section{Conclusions}

The Taguchi method proved that can be used as optimization method to determine the best parameters combination to obtain the minimum temperatures in the drilling process. The combination of parameters and levels which provide the minimum average temperature is A1B3C1. By ANOVA analysis was possible to verify that the irrigation parameter is the most influent in the drilling temperature.

\section{References}

[1] Eriksson RA, Albrektsson T. The effect of heat on bone regeneration: An experimental study in the rabbit using the bone growth chamber. Journal of Oral and Maxillofacial Surgery, 1984, 42: 705-711.

[2] Kurt M, Bagci E, Kaynak Y. Application of Taguchi methods in the optimization of cutting parameters for surface finish and hole diameter accuracy in dry drilling processes. Int J Adv Manuf Technol, 2009, 40: 458-469. [3] Pandey RK, Panda SS. Evaluation of delamination in drilling of bone. Medical Engineering and Physics, 2015, 37: $657-664$.

[4] Sampaio C., et al. The assessment of the generated temperature by the drill bit in the bone tissue. In Proceedings of III International Coference of Biodental Engineering, Porto, Portugal, 22-23 June, 2014 